\title{
ANALISIS KINERJA BISNIS INTERNAL PERUSAHAAN PUPUK ORGANIK CV MULIA ORGANIK TURI SLEMAN
}

\author{
Sunardi ${ }^{1)}$ Akimi $^{2}$ ) \\ 1) Sekolah Tinggi Penyuluhan Pertanian (STPP) Magelang \\ ${ }^{2)}$ Staf Pengajar Sekolah Tinggi Penyuluhan Pertanian (STPP) Magelang \\ Email : caknardi762@gmail.com
}

\begin{abstract}
Analysis of Internal Business Performance of CV Mulia Organik Turi Sleman Organic Fertilizer Company
\end{abstract}

\begin{abstract}
The purpose of this study was to analyze the internal business performance of organic fertilizer companies, CV Mulia Organik during the 2014-2016 period. This research is a case study, the selection method uses purposive sampling. While respondents consisted of nine employee respondents and two respondents of CV Mulia Organik customers. Data collection methods are obtained from secondary data secondary data with documentation. This research was conducted using an internal business perspective with Supply Lead Time (SLT) and capacity calculations. The results obtained result that overall internal business performance of the CV Mulia Organic, it's performance not good.
\end{abstract}

Keywords: Performance, Internal Business, Organic Fertilizer.

\section{PENDAHULUAN}

Dewasa ini banyak ditemukan berbagai permasalahan akibat kesalahan manajemen di lahan pertanian yaitu pencemaran oleh pupuk kimia dan pestisida kimia. Pemakaian bahan-bahan terutama tercemar oleh bahan-bahan sintesis tersebut secara berlebihan berdampak terhadap penurunan kualitas lingkungan, kesehatan manusia maupun penurunan produktivitas lahan pertanian. Rendahnya produktivitas lahan berakibat tanah menjadi jenuh. Kejenuhan tanah ini mengakibatkan penyerapan unsur makro tanah tidak bisa maksimal diserap oleh akar tanaman.

Menurut Syamsu (2013), kandungan unsur hara dalam pupuk organik terutama pupuk kandang tidak terlalu tinggi tetapi keunggulan lain dari pupuk ini mampu memperbaiki sifat-sifat fisik tanah seperti daya menahan air, porositas, struktur, permeabilitas, serta kation-kation tanah. Beberapa kondisi tanah miskin hara, tanah pasir atau tanah yang banyak tererosi sebaiknya dipupuk dengan pupuk organik daripada dengan pupuk buatan karena apabila pemberian pupuk buatan pada kondisi tanah tersebut maka tanah tersebut akan mudah sekali tercuci oleh air hujan. Pemberian pupuk organik akan mampu meningkatkan daya menahan air pada tanah dan kation-kation tanah menjadi meningkat sehingga mampu menghambat pencucian oleh air hujan dan erosi tanah.

Menurut Wahyudi dan Fanani (2013), agar tanah tidak jenuh dan kapasitas tukar kation (KTK) tinggi, dan akar tanaman mampu menyerap efektif unsur hara maka perlu peningkatan BOT agar persentasenya mendekati $5 \%$ atau di atasnya dapat dilakukan dengan memasukkan bahan organik atau kompos ke dalam tanah atau lahan pertanian.

Menurut Suntoro (2006) akibat dari ditinggalkannya penggunaan pupuk organik berdampak pada penyusutan kandungan 
bahan organik tanah, bahkan banyak tempat-tempat yang kandungan bahan organiknya sudah sampai pada tingkat rawan, sekitar 60 persen areal sawah di Jawa kandungan bahan organiknya kurang dari 1 persen. Sementara, sistem pertanian bisa menjadi sustainable (berkelanjutan) jika kandungan bahan organik tanah lebih dari $2 \%$. Bahan organik tanah disamping memberikan unsur hara tanaman yang lengkap juga akan memperbaiki struktur tanah, sehingga tanah akan semakin remah. Namun jika penambahan bahan organik tidak diberikan dalam jangka panjang kesuburan fisiknya akan semakin menurun.

Kaplan dan Norton (1996) membagi proses bisnis internal ke dalam tiga tahapan, yaitu:

\section{a. Proses inovasi}

Dalam proses penciptaan nilai tambah bagi pelanggan, proses inovasi merupakan salah satu kritikal proses, dimana efisiensi dan efektifitas serta ketepatan waktu dari proses inovasi ini akan mendorong terjadinya efisiensi biaya pada proses penciptaan nilat tambah bagi pelanggan.

Dalam proses ini, unit bisnis menggali pemahaman tentang kebutuhan dari pelanggan dan menciptakan produk dan jasa yang mereka butuhkan. Proses inovasi dalam perusahaan biasanya dilakukan oleh bagian marketing sehingga setiap keputusan pengeluaran suatu produk ke pasar telah memenuhi syarat-syarat pemasaran dan dapat dikomersialkan (didasarkan pada kebutuhan pasar).

\section{b. Proses Operasi}

Proses operasi adalah proses untuk membuat dan menyampaikan produk/jasa. Aktivitas di dalam proses operasi terbagi ke dalam dua bagian: 1) proses pembuatan produk, dan 2) proses penyampaian produk kepada pelanggan. Pengukuran kinerja yang terkait dalam proses operasi dikelompokkan pada waktu, kualitas, dan biaya.

Pengukuran yang dilakukan untuk perspektif proses bisnis internal adalah:

1. Supplier lead time.

Supplier lead time merupakan waktu rata-rata yang diperlukan pemasok untuk mengirimkan barang yang dipesan.

\section{Part Per-million Defect Rate}

Tujuan menentukan pengukuran ini adalah untuk mengetahui tingkat kerusakan produk badan usaha bila di bandingkan dengan produksi perseluruhan badan usaha.

\section{Fleksibilitas}

Waktu set up, down time, pengalaman operator, kapasitas mesin, aktifitas pemeliharaan, kesiapan peralatan, di samping itu juga ada faktor keamanan yang perlu di perhatikan baik jumlah kecelakaan dalam proses produksi maupun dampak dari kecelakaan tersebut yang harus di kendalikan.

c. Proses Pelayanan Purna Jual

Proses ini merupakan jasa pelayanan pada pelanggan setelah penjualan produk/jasa tersebut dilakukan. Aktivitas yang terjadi dalam tahapan ini, misalnya penanganan garansi dan perbaikan penanganan atas barang rusak dan yang dikembalikan serta pemrosesan pembayaran pelanggan. Perusahaan dapat mengukur apakah upayanya dalam pelayanan purna jual ini telah memenuhi harapan pelanggan, dengan menggunakan tolak ukur yang bersifat kualitas, biaya, dan waktu seperti yang dilakukan dalam proses operasi. Untuk siklus waktu, perusahaan dapat menggunakan pengukuran waktu dari saat keluhan pelanggan diterima hingga keluhan tersebut diselesaikan. 
Sebagai perusahaan agribisnis, CV. Mulia Organik di Jl. Turi-Tempel KM 5 Desa Bangunkerto Turi Sleman Yogyakarta, secara khusus bergerak pada bidang produksi pupuk organik berbentuk granul untuk memenuhi kebutuhan pupuk organik bagi petani skala regional maupun nasional.

CV. Mulia Organik bekerja sama penyediaan pupuk dengan PT.Petrokimia divisi organik yaitu Petroganik dalam pemasaran produknya. Meskipun prospek CV. Mulia Organik masih terkendala dalam hal kemampuan mengelola sumber daya manusia/karyawan dan kemampuan untuk mencapai target maksimal perusahaan dalam meraih keuntungan.

Secara umum, persoalan mendasar yang terjadi di CV.Mulia Organik adalah tidak tercapainya target-target bisnis internalnya sehingga berpengaruh terhadap perusahaan dalam aspek pelanggan, produksi, kendala keuangan. Pengukuran kinerja bisnis internal yang dilakukan oleh pihak manajemen CV. Mulia Organik perlu dilakukan penelitian agar dapat digunakan untuk mengukur tingkat keberhasilan dari suatu strategi umum kegiatan bisnis yang sudah ditetapkan sebelumnya.

Oleh karena itu perlu dilakukan penelitian penilaian kinerja bisnis perusahaan Pupuk Organik CV.Mulia Organik Turi Sleman. Tujuan penelitian ini adalah menganalisis kinerja CV. Mulia Organik dari perspektif bisnis internal, rentang waktu 2014-2016.

\section{METODE PENELITIAN}

Penelitian ini dilakukan di CV. Mulia Organik di Desa Bangunkerto Kecamatan Turi Kabupaten Sleman. Penelitian dilakukan dari tanggal 15 Oktober sampai dengan 15 Desember 2017.

Data yang digunakan adalah data sekunder dengan metode pengambilan data pencatatan. Untuk menganalisis kinerja bisnis internal menggunakan Supplier Lead Time (SLT) dan capacity.

\section{a) Supplier Lead Time (SLT)}

Merupakan waktu rata-rata yang diperlukan CV. Mulia Organik dari proses pupuk yang dipesan sampai pupuk diterima oleh pemesan

Rumusnya:

$S L T=$ Jumlah Hari Pengiriman Pupuk

Total Waktu Pemesanan Pupuk Sampai Terkirim

b) Capacity

Merupakan mengukur rasio antara produksi nyata dengan kemampuan produksi CV.Mulia Organik.

Rumusnya:

Capacity $=\frac{\text { Total Produksi Pupuk CV.MO }}{\text { Kapasitas Pabrik CV.MO }} \times 100 \%$

\section{HASIL DAN PEMBAHASAN}

\section{Kinerja CV. Mulia Organik dari Perspektif Bisnis Internal}

1) Supplier Lead Time (SLT)

Merupakan waktu rata-rata yang diperlukan CV. Mulia Organik dari proses pupuk yang dipesan sampai pupuk diterima oleh pemesan. 
Rumusnya:

$S L T=\frac{\text { Total Waktu Pemesanan Pupuk Sampai Terkirim }}{\text { Jumlah Hari Pengiriman Pupuk }}$

Tabel 1. Hasil perhitungan Supplier Lead Time (SLT) CV.MO Tahun 2014-2016

\begin{tabular}{cccccc}
\hline \hline Tahun & $\begin{array}{c}\text { Total Waktu } \\
\text { Pemesanan Pupuk } \\
\text { Sampai Terkirim } \\
\text { (Hari) }\end{array}$ & $\begin{array}{c}\text { Jumlah hari } \\
\text { pengiriman Pupuk } \\
\text { (Hari) }\end{array}$ & SLT & Target & $\begin{array}{c}\text { \% Capaian } \\
\text { Target }\end{array}$ \\
\hline Jan-Jun 2014 & 60 & 14 & 4,29 & 90 & 4,77 \\
Juli-Des 2014 & 60 & 14 & 4,29 & 90 & 4,77 \\
Jan-Jun 2015 & 60 & 21 & 2,86 & 90 & 3,18 \\
Juli-Des 2015 & 60 & 21 & 2,86 & 90 & 3.18 \\
Jan-Jun 2016 & 75 & 21 & 3,57 & 90 & 3,97 \\
Juli-Des 2016 & 75 & 21 & 3,57 & 90 & 3,97 \\
& Rata-rata & & 3,57 & 90 & 3,97 \\
\hline
\end{tabular}

Pada tabel 1 terlihat bahwa nilai Supplier Lead Time (SLT) dari CV. Mulia Organik tertinggi dicapai tahun 2014 Januari-Juni 2015 4,29 dan terendah tahun 2016 sebesar 3,57. Untuk rata-rata SLT adalah 3,57.

Rendahnya nilai SLT disebabkan rendahnya kemampuan mengelola produksi, stabilitas bahan baku serta kualitas mesin-mesin produksi serta kemampuan SDM bekerja sesuai tugasnya. Hal ini menyebabkan waktu produksi semakin panjang dan berpengaruh pada lamanya waktu pengiriman pupuk.

\section{2) Capacity}

Rumus yang digunakan untuk menghitung Capacity adalah :

Capacity $=\frac{\text { Total Produksi }}{\text { Kapasitas Pabrik }}$

Hasil perhitungan capacity dari CV.Mulia Organik tertera pada tabel 2

Tabel 2. Hasil perhitungan capacity CV.Mulia Organik Tahun 2014-2016

\begin{tabular}{llcccc}
\hline \multicolumn{1}{c}{ Tahun } & $\begin{array}{c}\text { Total Produksi } \\
\text { Pupuk (Ton) }\end{array}$ & $\begin{array}{c}\text { Kapasitas Pabrik } \\
(\text { Ton) }\end{array}$ & $\begin{array}{c}\text { Capacity } \\
(\%)\end{array}$ & $\begin{array}{c}\text { Target } \\
(\%)\end{array}$ & $\begin{array}{c}\text { \% Capaian } \\
\text { Target }\end{array}$ \\
\hline Jan-Jun 2014 & 1.570 & 3.000 & 52,33 & 75 & 69,77 \\
Juli-Des 2014 & 1.300 & 3.000 & 43,33 & 75 & 57,77 \\
Jan-Jun 2015 & $1.332,32$ & 3.000 & 44,41 & 75 & 59,21 \\
Juli-Des 2015 & $1.840,8$ & 3.000 & 61,36 & 75 & 81,81 \\
Jan-Jun 2016 & $2.108,76$ & 3.000 & 70,29 & 75 & 93,72 \\
Juli-Des 2016 & 464,88 & 3.000 & 15,5 & 75 & 20,67 \\
& Rata-rata & & 47,87 & 75 & 63,83 \\
\hline
\end{tabular}

CV. Mulia Organik mempunyai kapasitas produksi pabrik sebesar 3.000 ton. Namun selama periode 2014 sampai dengan 2016 perusahaan ini tidak pernah memproduksi sebesar kapasitas pabriknya. Produksi tertinggi terlihat pada Januari-Juni 2016 tahun 2016 yaitu sebesar 70,29\% dari kapasitas pabrik. Produksi terendah terjadi pada Juli-Desember tahun 2016 yaitu sebesar 464,88 ton atau setara dengan 15,5\% dari kapasitas pabrik. Perusahaan ini mempunyai rata-rata produksi per tahun sebesar $47,87 \%$ selama periode 2014 sampai dengan 2016. 
Nilai capacity masih rendah dimiliki. Kemampuan atau kapasitas pabrik dipengaruhi rendahnya nilai maksimal rendah banyak dipengaruhi kemampuan produksi pupuk yang mampu diproduksi mesin yang menurun dan SDM yang oleh CV Mulia Organik dibandingkan dimiliki tidak mampu menunjukkan dengan kapasitas pabrik yang seharusnya kemampuan maksimal.

Tabel 3. Nilai Perhitungan Capaian Target Perspektif Bisnis Internal.

\begin{tabular}{|c|l|c|c|c|}
\hline No & \multicolumn{1}{|c|}{ Perspektif Bisnis Internal } & $\begin{array}{c}\text { Rata-rata Nilai } \\
(\%)\end{array}$ & Target Nilai (\%) & $\begin{array}{c}\text { \% Capaian } \\
\text { Target }\end{array}$ \\
\hline 1 & Supplier Lead Time (SLT) & 3,57 & 90 & 3,97 \\
\hline 2 & Capacity & 47,87 & 75 & 63,83 \\
\hline
\end{tabular}

Berdasarkan tabel 3 bahwa nilai persentase pencapaian target perspektif bisnis internal masih di bawah target perusahaan. Hal ini disebabkan parameter pengukuran perspektif bisnis internal yaitu Supplier Lead Time (SLT) dan Capacity juga masih dibawah target.

\section{KESIMPULAN DAN SARAN}

\section{A. Kesimpulan}

Kinerja bisnis internal perusahaan pupuk organik CV Mulia Organik dalam rentang waktu tahun 2014-2016 tidak baik dilihat dari Supplier Lead Time (SLT) dan Capacity.

\section{B. Saran}

Berdasarkan hasil dari penelitian dapat disarankan:

1. CV Mulia Organik harus meningkatkan kemampuan produksi,

2. CV Mulia Organik perlu peningkatan kapasitas mesin

3. CV Mulia Organik menjaga stabilitas bahan baku

4. Meningkatkan evaluasi kemampuan SDM agar bekerja sesuai tugasnya.

\section{DAFTAR PUSTAKA}

Kaplan, Robert S. dan David P, Norton. 1996. Translating Strategy Into Action. Balanced Scorecard. Boston: Harvard Business School Press.

Suntoro, W.A. 2006. Degradasi Lahan dan Ancaman Bagi Pertanian. Solo:Solo Pos.

Syamsu, Ida, Roidah. 2013. Manfaat Penggunaan Pupuk Organik Untuk Kesuburan Tanah. Jurnal Universitas Tulungagung Bonorowo. Vol. 1.No.1 Tahun 2013.

Wahyudi dan Fanani, Zaenal. 2013. Jurnal Manajemen Agribisnis: Strategi Pengembangan Agribisnis Pupuk Organik di CV. Mitra Tani, Kecamatan Kunjang, Kabupaten Kediri. Kediri. Vol 13, No. 2, Juli 2013.. 